\title{
Analisis Kompetensi Profesional, Pedagogik, Sosial dan Kepribadian Mahasiswa
}

\author{
Jofri Boimau, Nani Mediatati \\ 1,2,3 Program Studi Pendidikan Pancasila dan Kewarganegaraan \\ Fakultas Keguruan dan Ilmu Pendidikan \\ Universitas Kristen Satya Wacana Salatiga
}

Email: jofriboimau@gmail.co.id

\begin{abstract}
ABSTRAK
Tujuan dari penelitian ini adalah untuk mendeskripsikan tingkat penguasaan kompetensi profesional, pedagogis, pribadi dan sosial mahasiswa PPKn yang melaksanakan program magang III di SMKN 2 \& 3 Salatiga. Jenis penelitian ini adalah penelitian deskriptif. Teknik pengumpulan data menggunakan studi dokumen, wawancara, dan observasi. Teknik analisis data menggunakan teknik deskriptif kuantitatif. Subjek penelitian adalah 7 mahasiswa PPKn Peserta Magang III. Hasil penelitian menunjukkan tingkat penguasaan kompetensi pedagogis dan profesional mahasiswa PPKn sebagai peserta magang III yang ditunjukkan kemampuan untuk menyusun rencana pelajaran, melaksanakan rencana pelajaran dalam kategori kelas dalam kategori baik dan sangat baik, dengan skor rata-rata 3,02 ke 3,97. Penguasaan 7 indikator kompetensi dinilai, 4 mahasiswa dinilai sangat baik dengan skor rata-rata 4, dan 3 mahasiswa indikator 4 dan 7 dinilai baik dengan skor 3, rata-rata juga 3,71 kategori sangat baik. 5 indikator kompetensi sosial dinilai, 4 mahasiswa dinilai sangat baik, skor rata-rata 4 dan 3 mahasiswa indikator 3 dan 4 dinilai baik dengan skor 3, rata-rata 3,80, kategori sangat baik. Hasil penelitian dapat disimpulkan penguasaan kompetensi guru, mahasiswa yang melaksanakan program magang III rata-rata sangat baik dalam melaksanakan tugas sebagai calon guru profesional.
\end{abstract}

Kata Kunci: Kompetensi; Pedagogik; Profesional; Kepribadian; Sosial.

\begin{abstract}
The purpose of this research is to describe the level of mastery of professional, pedagogical, personal and social competency of PPKn college student who carry out an internship program III at SMKN 2 \& 3 Salatiga. This type of research is descriptive research. Data collection techniques using document studies, interviews, and observations. Data analysis techniques using quantitative descriptive techniques. The research subjects were 7 college student of PPKn Internship III Participants. The results showed the level of mastery of pedagogical and professional competencies of PPKn college student as apprentice III participants who were shown the ability to compile lesson plans, implement lesson plans in class categories in both good and very good categories, with an average score of 3.02 to 3.97. The mastery of 7 competency indicators was assessed, 4 college student were rated very well with an average score of 4 , and 3 college student on indicators 4 and 7 were rated well with a score of 3 , the average was also 3.71 the category was very good. 5 indicators of social competency were assessed, 4 college student rated very good, the average score of 4 and 3 college student on indicators 3 and 4 were rated as good with a score of 3, the average was 3.80, the category was very good. The results of the study can be concluded mastery of teacher competency, college student who carry out an internship program III on average are very good at carrying out tasks as a prospective professional teacher.
\end{abstract}

Keywords : Competence; Pedagogical; Professional; Personality; Social. 


\section{PENDAHULUAN}

Menurut amanat Undang-Undang Nomor 14 Tahun 2005 Bab IV pasal 10 tentang Guru dan Dosen, terdapat empat kompetensi mengajar yang harus dikuasai oleh seorang tenaga pendidik, yaitu kompetensi pedagogik, kompetensi kepribadian, kompetensi profesional dan kompetensi sosial. (Sumardjono Padmomartono, 2009) menyatakan bahwa penguasan empat kompetensi tersebut mutlak perlu dimiliki tiap guru untuk menjadi tenaga pendidik yang profesional seperti yang disyaratkan Undang Undang Guru Dan Dosen.

Kompetensi pedagogik adalah pemahaman guru terhadap siswa, perancangan dan pelaksanaan pembelajaran, evaluasi hasil belajar, dan pengembangan siswa untuk mengaktualisasikan berbagai potensi yang dimilikinya, kompetensi profesional merupakan penguasan materi pembelajaran secara luas dan mendalam yang harus dikuasai guru mencakup penguasan materi kurikulum mata pelajaran di sekolah dan subtansi keilmuan yang menaungi materi, serta penguasan terhadap struktur dan metodologi keilmuan, kompetensi kepribadian merupakan kemampuan personal yang mencerminkan kepribadian yang mantap, stabil, dewasa, arif, berakhlak mulia dan berwibawa, dan dapat menjadi teladan bagi siswa, serta kompetensi sosial merupakan kemampuan yang harus dimiliki guru untuk berkomunikasi dan bergaul secara efektif dengan siswa, sesama pendidik, tenaga kependidikan, orangtua/wali siswa dan masyarakat sekitar.

Progdi PPKn sebagai salah satu progdi di Fakultas Keguruan dan Ilmu Pendidikan (FKIP) UKSW yang menghasilkan tenaga pendidik/guru PPKn di jenjang SD sampai dengan Sekolah Menengah dalam menyelenggarakan pendidikannya juga diarahkan untuk mempersiapkan mahasiswanya menjadi guru yang profesional yang menguasai 4 kompetensi guru tersebut.

Dalam kurikulumnya selain memberikan mata kuliah teori terkait dengan bidang studi dan dasar dasar kependidikan, juga diberikan mata kuliah yang bersifat praktek kependidikan di sekolah yang disebut dengan mata kuliah/program magang. Program magang ini dilaksanakan 3 kali yaitu magang I, magang II dan magang III. Magang I dilaksanakan pada semester 1 tahun kedua 


\section{PEDAGOGIKA}

\section{Volume 11 (Nomor 1) 2020}

Hal. 26-41

di sekolah, dimana mahasiswa mulai dikenalkan dengan dunia sekolah dengan berbagai kegiatan yang dilakukan oleh guru dan siswa. Program magang I ini bertujuan untuk membangun landasan jati diri pendidik, untuk membekali mahasiswa agar cakap melakukan observasi dan penghayatan langsung berbagai kehidupan di sekolah. (Buku panduan magang I, 2017) Selanjutnya magang II dilaksanakan pada semester 1 tahun ketiga di sekolah yang sama, dimana mahasiswa mulai diajarkan untuk menyusun perangkat pembelajaran (Prota, Prosem, Silabus, RPP, Media Pembelajaran, dan Evaluasi Pembelajaran) tetapi belum mengajar di kelas. Program magang II bertujuan untuk memantapkan kompetensi akademik kependidikan dan serangkaian kegiatan yang di programkan untuk memberi pengalaman kepada mahasiswa / calon guru dalam menelaah, merancang, dan mengembangkan segenap komponen dalam sistem pembelajaran di sekolah. (Buku panduan Magang II, 2017).

Kemudian program Magang III dilaksanakan pada semester 1 tahun ke empat di sekolah yang sama juga, dimana mahasiswa sudah harus mengajar di kelas didampingi oleh guru pamong untuk mempraktekan perangkat pembelajaran yang telah disusun/dibuat. Dalam program magang III ini pada prinsipnya bahwa hasil dan segala pengalaman mahasiswa dalam menelaah, merancang, dan mengembangkan perangkat pembelajaran pada magang II digunakan dalam proses pembelajaran dengan merasakan langsung mengajar pada mata pelajaran (asisten guru) yang bertujuan untuk memberikan pengalaman awal kepada calon guru dalam mengimplementasikanpenguasan akademik kependidikan dan akademik bidang keahlian.(Buku panduan Magang III, 2017). Pada program magang III inilah mahasiswa diharapkan dapat menguasai ke empat kompetensi guru yang profesional yaitu kompetensi pedagogik, profesional, kepribadian dan sosial. Penilaian terhadap penguasaan ke empat kompetensi tersebut dilakukan oleh guru pamong dan dosen pembimbing melalui lembar penilaian penyusunan RPP, pelaksanaan RPP di kelas, kompetensi kepribadian dan kompetensi sosial dengan penjabarannya dalam berbagai indikator penilaian. Tingkat penguasaan ke empat kompetensi inilah yang menentukan kelulusan mahasiswa dari program magang III yang sekaligus menunjukkan kesiapan mahasiswa untuk menjadi calon guru yang profesional.

Berkaitan dengan hal tersebut maka penting dilakukan penelitian untuk mengetahui tingkat penguasaan kompetensi pedagogik, profesional, kepribadian dan 
PEDAGOGIKA

Volume 11 (Nomor 1) 2020

Hal. 26-41

sosial mahasiswa progdi PPKn peserta magang III yang dikemas dengan judul Analisis Penguasaan Kompetensi Profesional, Pedagogik, Sosial Dan Kepribadian Mahasiswa progdi PPKn Yang Melaksanakan Program Magang III Di SMKN 2\&3 Salatiga Pada Semester Ganjil Tahun 2018/2019.

\section{METODE PENELITIAN}

Jenis penelitian yang digunakan adalah penelitian deskriptif. Menurut Moleong dalam Herdiansyah (2010:9) penelitian kualitatif adalah suatu penelitian ilmiah yang bertujuan untuk memahami suatu fenomena dalam konteks sosial secara alamiah dengan mengedepankan proses interaksi komunikasi mendalam antara peneliti dan fenomena yang diteliti. Meskipun demikian, dalam penelitian ini metode kuantitatif tetap akan digunakan untuk mengolah data yang bersifat numerik, khususnya untuk lembar penilaian magang III. Teknik pengumpulan data menggunakan studi dokumen (lembar penilaian magang III yang terdiri dari lembar penilaian penyusunan RPP, pelaksanaan RPP, kompetensi kepribadian dan sosial), wawancara dan observasi. Subjek penelitian ini adalah 7 orang mahasiswa yang terbagi 4 orang magang III di SMKN 2 Salatiga dan 3 orang magang III di SMKN 3 Salatiga. Waktu penelitian dari bulan September sampai dengan Desember 2018 sesuai waktu pelaksanaan magang III di sekolah. Teknik analisis data menggunakan teknik deskriptif kuantitatif yang menggambarkan tingkat penguasaan kompetensi pedagogik, profesional, kepribadian dan sosial mahasiswa PPKn yang melaksanakan program magang III.

$$
\text { Hasil penelitian ini }
$$
mendeskripsikan data tentang tingkat penguasaan 4 kompetensi guru (kompetensi pedagogik, profesional, sosial, dan kepribadian) dari mahasiswa Program Studi PPKn Universitas Kristen Satya Wacana peserta magang III di SMKN 2 dan SMKN 3 Salatiga semester ganjil 2018/2019 berdasarkan penilaian dari guru pamong dan dosen pembimbing. Pengambilan data dilakukan melalui lembar penilaian RPP dan pelaksanaan RPP untuk kompetensi pedagogik dan profesional, dan lembar penilaian Kompentensi sosial dan Kompetensi kepribadian, selama 4x latihan mengajar dan 1x ujian (studi dokumen), serta wawancara dengan guru pamong dan dosen pembimbing dan observasi di kelas saat mahasiswa latihan mengajar.

Hasil penelitian dapat di deskripsikan sebagai berikut;

a. Penguasaan Kompetensi Profesional dan Pedagogik mahasiswa Progdi PPKn peserta magang III berdasarkan penilaian terhadap penyusunan RPP (

\section{Pedagogika.fip@ung.ac.id P-ISSN : 2086-4469 E-ISSN : 2716-0580}




\section{PEDAGOGIKA}

\section{Volume 11 (Nomor 1) 2020}

\section{Hal. 26-41}

Rencana Pelaksanaan Pembelajaran)

dari 4x Latihan dan 1x Ujian.

Penguasaan kompetensi profesional dan pedagogik berdasarkan penilaian penyusunan RPP dapat dilihat pada tabel 01-02 berikut ini.

Tabel 1. Penilaian penyusunan RPP

\begin{tabular}{|c|c|c|c|c|c|c|c|c|c|c|c|c|c|c|c|c|c|c|c|c|c|}
\hline \multirow[t]{2}{*}{$\begin{array}{l}\mathrm{N} \\
\mathrm{O}\end{array}$} & \multirow{2}{*}{$\begin{array}{l}\text { Unsur } \\
\text { yang } \\
\text { dinilai }\end{array}$} & & $\begin{array}{r}\mathrm{M} \\
\text { atih } \\
\mathrm{U}\end{array}$ & $\begin{array}{l}\mathrm{H} 1 \\
\mathrm{nd} \\
\text { an }\end{array}$ & & \multicolumn{6}{|c|}{$\begin{array}{c}\text { MH2 } \\
\text { Latihan dan Ujian }\end{array}$} & \multicolumn{4}{|c|}{$\begin{array}{l}\text { MH3 } \\
\text { Latihan dan } \\
\text { Ujain }\end{array}$} & \multicolumn{6}{|c|}{$\begin{array}{c}\text { MH4 } \\
\text { Latihan dan ujian }\end{array}$} \\
\hline & & 1 & 2 & 3 & 4 & $\mathbf{U}$ & 1 & 2 & 3 & 4 & $\mathbf{U}$ & $\mathbf{1}$ & 2 & 3 & 4 & $\mathbf{U}$ & 1 & 2 & 3 & 4 & $\mathbf{U}$ \\
\hline 1 & $\begin{array}{l}\text { Perumus } \\
\text { an } \\
\text { indikato } \\
\mathrm{r} \\
\text { pembela } \\
\text { jaran }\end{array}$ & $\begin{array}{l}3 \\
0 \\
0\end{array}$ & $\begin{array}{l}4, \\
0 \\
0\end{array}$ & $\begin{array}{l}4 \\
0 \\
0\end{array}$ & $\begin{array}{l}4, \\
0 \\
0\end{array}$ & $\begin{array}{l}4, \\
0 \\
0\end{array}$ & $\begin{array}{l}3 . \\
0 \\
0\end{array}$ & $\begin{array}{l}3 \\
66\end{array}$ & $\begin{array}{l}4, \\
0 \\
0\end{array}$ & $\begin{array}{l}4, \\
0 \\
0\end{array}$ & $\begin{array}{l}4 \\
0 \\
0\end{array}$ & $\begin{array}{l}3, \\
0 \\
0\end{array}$ & $\begin{array}{l}3, \\
0 \\
0\end{array}$ & $\begin{array}{l}3, \\
0 \\
0\end{array}$ & $\begin{array}{l}4, \\
0 \\
0\end{array}$ & $\begin{array}{l}4, \\
0 \\
0\end{array}$ & 3 , & $\begin{array}{l}3, \\
3 \\
3\end{array}$ & $\begin{array}{l}3, \\
6 \\
6\end{array}$ & $\begin{array}{l}4, \\
0 \\
0\end{array}$ & $\begin{array}{l}4,0 \\
0\end{array}$ \\
\hline 2 & $\begin{array}{l}\text { Pengorg } \\
\text { anisasia } \\
\mathrm{n} \text { dan } \\
\text { pemiliha } \\
\mathrm{n} \text { materi } \\
\text { ajar }\end{array}$ & $\begin{array}{l}3 \\
0 \\
0\end{array}$ & $\begin{array}{l}3, \\
7 \\
5\end{array}$ & $\begin{array}{l}3 \\
7 \\
5\end{array}$ & $\begin{array}{l}4, \\
0 \\
0\end{array}$ & $\begin{array}{l}4, \\
0 \\
0\end{array}$ & $\begin{array}{l}3, \\
0 \\
0\end{array}$ & $\begin{array}{l}3, \\
50\end{array}$ & $\begin{array}{l}3, \\
7 \\
5\end{array}$ & $\begin{array}{l}3, \\
7 \\
5\end{array}$ & $\begin{array}{l}4 \\
. \\
0 \\
0\end{array}$ & $\begin{array}{l}3, \\
0 \\
0\end{array}$ & $\begin{array}{l}3, \\
2 \\
5\end{array}$ & $\begin{array}{l}3, \\
5 \\
0\end{array}$ & $\begin{array}{l}3, \\
7 \\
5\end{array}$ & $\begin{array}{l}3, \\
7 \\
5\end{array}$ & 5 & $\begin{array}{l}3, \\
5 \\
0\end{array}$ & $\begin{array}{l}3, \\
7 \\
5\end{array}$ & $\begin{array}{l}3, \\
7 \\
5\end{array}$ & $\begin{array}{l}4,0 \\
0\end{array}$ \\
\hline 3 & $\begin{array}{l}\text { Pemilih } \\
\text { an } \\
\text { sumber } \\
\text { belajar / } \\
\text { media } \\
\text { pembela } \\
\text { jaran }\end{array}$ & $\begin{array}{l}4 \\
0 \\
0\end{array}$ & $\begin{array}{l}4, \\
0 \\
0\end{array}$ & $\begin{array}{l}3 \\
6 \\
6\end{array}$ & $\begin{array}{l}4, \\
0 \\
0\end{array}$ & $\begin{array}{l}3, \\
6 \\
6\end{array}$ & $\begin{array}{l}3, \\
0 \\
0\end{array}$ & $\begin{array}{l}3, \\
33\end{array}$ & $\begin{array}{l}3, \\
6 \\
6\end{array}$ & $\begin{array}{l}3, \\
6 \\
6\end{array}$ & $\begin{array}{l}4 \\
0 \\
0\end{array}$ & $\begin{array}{l}3, \\
0 \\
0\end{array}$ & $\begin{array}{l}3, \\
3 \\
3\end{array}$ & $\begin{array}{l}3, \\
6 \\
6\end{array}$ & $\begin{array}{l}3, \\
6 \\
6\end{array}$ & $\begin{array}{l}4, \\
0 \\
0\end{array}$ & 3 & $\begin{array}{l}3, \\
6 \\
6\end{array}$ & $\begin{array}{l}3, \\
6 \\
6\end{array}$ & $\begin{array}{l}3, \\
6 \\
6\end{array}$ & $\begin{array}{l}4,0 \\
0\end{array}$ \\
\hline 4 & $\begin{array}{l}\text { Scenario } \\
\text { / } \\
\text { kegiatan } \\
\text { pembela } \\
\text { jaran }\end{array}$ & $\begin{array}{l}3 \\
0 \\
0\end{array}$ & $\begin{array}{l}3, \\
6 \\
6\end{array}$ & $\begin{array}{l}3 \\
5 \\
0\end{array}$ & $\begin{array}{l}3, \\
5 \\
0\end{array}$ & $\begin{array}{l}3, \\
6 \\
6\end{array}$ & $\begin{array}{l}3, \\
0 \\
0\end{array}$ & $\begin{array}{l}3, \\
50\end{array}$ & $\begin{array}{l}3, \\
6 \\
6\end{array}$ & $\begin{array}{l}3, \\
6 \\
6\end{array}$ & $\begin{array}{l}3 \\
8 \\
3\end{array}$ & $\begin{array}{l}3, \\
3 \\
3\end{array}$ & $\begin{array}{l}3, \\
5 \\
0\end{array}$ & $\begin{array}{l}3, \\
5 \\
0\end{array}$ & $\begin{array}{l}3, \\
6 \\
6\end{array}$ & $\begin{array}{l}3, \\
8 \\
3\end{array}$ & 3 & $\begin{array}{l}3, \\
5 \\
0\end{array}$ & $\begin{array}{l}3, \\
6 \\
6\end{array}$ & $\begin{array}{l}3, \\
8 \\
3\end{array}$ & $\begin{array}{l}3,8 \\
3\end{array}$ \\
\hline 5 & $\begin{array}{l}\text { Penilaia } \\
\mathrm{n} \text { hasil } \\
\text { belajar }\end{array}$ & $\begin{array}{l}3 \\
0 \\
0\end{array}$ & $\begin{array}{l}3, \\
0 \\
0\end{array}$ & $\begin{array}{l}4 \\
0 \\
0\end{array}$ & $\begin{array}{l}3, \\
7 \\
5\end{array}$ & $\begin{array}{l}3, \\
7 \\
5\end{array}$ & $\begin{array}{l}3, \\
0 \\
0\end{array}$ & $\begin{array}{l}3, \\
50\end{array}$ & $\begin{array}{l}3, \\
7 \\
5\end{array}$ & $\begin{array}{l}3, \\
7 \\
5\end{array}$ & $\begin{array}{l}3 \\
7 \\
7 \\
5\end{array}$ & $\begin{array}{l}3, \\
2 \\
5\end{array}$ & $\begin{array}{l}3, \\
5 \\
0\end{array}$ & $\begin{array}{l}4, \\
0 \\
0\end{array}$ & $\begin{array}{l}4, \\
0 \\
0\end{array}$ & $\begin{array}{l}4, \\
0 \\
0\end{array}$ & 5 & $\begin{array}{l}3, \\
5 \\
0\end{array}$ & $\begin{array}{l}3, \\
7 \\
5\end{array}$ & $\begin{array}{l}3, \\
7 \\
5\end{array}$ & $\begin{array}{l}3,7 \\
5\end{array}$ \\
\hline & Jumlah & $\begin{array}{l}1 \\
6 \\
0\end{array}$ & $\begin{array}{l}1 \\
8 . \\
4\end{array}$ & $\begin{array}{l}1 \\
8 \\
9\end{array}$ & $\begin{array}{l}1 \\
9 . \\
2\end{array}$ & $\begin{array}{l}1 \\
9 . \\
7\end{array}$ & $\begin{array}{l}1 \\
5 . \\
0\end{array}$ & $\begin{array}{l}17 \\
.4 \\
9\end{array}$ & 8 & $\begin{array}{l}1 \\
8 . \\
8\end{array}$ & $\begin{array}{l}1 \\
9 \\
\dot{2} \\
5\end{array}$ & $\begin{array}{l}1 \\
5 . \\
5 \\
6\end{array}$ & $\begin{array}{l}1 \\
6 . \\
6 \\
0\end{array}$ & $\begin{array}{l}1 \\
7 . \\
6 \\
6\end{array}$ & $\begin{array}{l}1 \\
9 . \\
0 \\
7\end{array}$ & $\begin{array}{l}1 \\
9 . \\
5 \\
8\end{array}$ & 5 & $\begin{array}{l}1 \\
7 . \\
5 \\
0\end{array}$ & $\begin{array}{l}1 \\
8 . \\
4 \\
9\end{array}$ & $\begin{array}{l}1 \\
9 . \\
0 \\
0\end{array}$ & $\begin{array}{l}19 . \\
54\end{array}$ \\
\hline & $\begin{array}{l}\text { Rata } \\
\text { Rata }\end{array}$ & $\begin{array}{l}3 \\
2\end{array}$ & $\begin{array}{l}3 . \\
6 \\
8\end{array}$ & $\begin{array}{l}3 \\
7 \\
8\end{array}$ & $\begin{array}{l}3 . \\
8 \\
5\end{array}$ & $\begin{array}{l}3 . \\
8 \\
1\end{array}$ & $\begin{array}{l}3 . \\
0 \\
0\end{array}$ & $\begin{array}{l}3 . \\
49\end{array}$ & $\begin{array}{l}7 \\
6\end{array}$ & $\begin{array}{l}3 . \\
7 \\
6\end{array}$ & $\begin{array}{l}3 \\
8 \\
8\end{array}$ & $\begin{array}{l}3 . \\
1 \\
2\end{array}$ & $\begin{array}{l}3 . \\
3 \\
2\end{array}$ & $\begin{array}{l}3 . \\
5 \\
3\end{array}$ & $\begin{array}{l}3 . \\
8 \\
1\end{array}$ & $\begin{array}{l}3 . \\
9 \\
1\end{array}$ & 5 & $\begin{array}{l}3 . \\
5 \\
0\end{array}$ & $\begin{array}{l}3 . \\
7 \\
0\end{array}$ & $\begin{array}{l}3 . \\
8 \\
0\end{array}$ & $\begin{array}{l}3.9 \\
0\end{array}$ \\
\hline
\end{tabular}

Tabel 2. Penilaian penyusunan RPP

\begin{tabular}{|c|c|c|c|c|c|c|c|c|c|c|c|c|c|c|c|c|}
\hline \multirow[t]{2}{*}{$\begin{array}{l}\mathrm{N} \\
\mathrm{O}\end{array}$} & \multirow[t]{2}{*}{$\begin{array}{l}\text { Unsur yang } \\
\text { dinilai }\end{array}$} & \multicolumn{4}{|c|}{$\begin{array}{l}\text { MH5 } \\
\text { Latihan dan } \\
\text { Ujian }\end{array}$} & \multicolumn{5}{|c|}{$\begin{array}{c}\text { MH6 } \\
\text { Latihan dan Ujian }\end{array}$} & & \multicolumn{5}{|c|}{$\begin{array}{c}\text { MH7 } \\
\text { Latihan dan ujian }\end{array}$} \\
\hline & & 1 & 2 & 3 & 4 & $\mathbf{U}$ & 1 & 2 & 3 & 4 & $\mathbf{U}$ & 1 & 2 & 3 & 4 & $\mathbf{U}$ \\
\hline 1 & $\begin{array}{l}\text { Perumusan } \\
\text { indikator } \\
\text { pembelajaran }\end{array}$ & $\begin{array}{l}3, \\
0 \\
0\end{array}$ & $\begin{array}{l}3, \\
3 \\
3\end{array}$ & $\begin{array}{l}3 \\
6 \\
6\end{array}$ & $\begin{array}{l}4, \\
0 \\
0\end{array}$ & $\begin{array}{l}4, \\
0 \\
0\end{array}$ & $\begin{array}{l}3, \\
3 \\
3\end{array}$ & $\begin{array}{l}3, \\
6 \\
6\end{array}$ & $\begin{array}{l}3,6 \\
6\end{array}$ & $\begin{array}{l}4,0 \\
0\end{array}$ & $\begin{array}{c}4,0 \\
0\end{array}$ & $\begin{array}{c}3,3 \\
3\end{array}$ & 3,66 & $\begin{array}{l}3, \\
66\end{array}$ & $\begin{array}{c}3,6 \\
6\end{array}$ & $\begin{array}{l}4, \\
00\end{array}$ \\
\hline 2 & $\begin{array}{l}\text { Pengorganisasian } \\
\text { dan pemilihan } \\
\text { materi ajar }\end{array}$ & $\begin{array}{l}3, \\
0 \\
5\end{array}$ & $\begin{array}{l}3, \\
2 \\
5\end{array}$ & $\begin{array}{l}3, \\
5 \\
0\end{array}$ & $\begin{array}{l}3 \\
7 \\
5\end{array}$ & $\begin{array}{l}4, \\
0 \\
0\end{array}$ & $\begin{array}{l}3, \\
2 \\
5\end{array}$ & $\begin{array}{l}3, \\
5 \\
0\end{array}$ & $\begin{array}{l}3,7 \\
5\end{array}$ & $\begin{array}{l}3,7 \\
5\end{array}$ & $\begin{array}{l}3,7 \\
5\end{array}$ & $\begin{array}{l}3,5 \\
0\end{array}$ & 3,50 & $\begin{array}{l}3 \\
75\end{array}$ & $\begin{array}{l}3,7 \\
5\end{array}$ & $\begin{array}{l}4, \\
00\end{array}$ \\
\hline 3 & $\begin{array}{l}\text { Pemilihan } \\
\text { sumber belajar / }\end{array}$ & $\begin{array}{l}3, \\
0\end{array}$ & $\begin{array}{l}3, \\
6\end{array}$ & $\begin{array}{l}3, \\
6\end{array}$ & $\begin{array}{l}3, \\
6\end{array}$ & $\begin{array}{l}4, \\
0\end{array}$ & $\begin{array}{l}3, \\
3\end{array}$ & $\begin{array}{l}3, \\
6\end{array}$ & $\begin{array}{l}3,6 \\
6\end{array}$ & $\begin{array}{l}4,0 \\
0\end{array}$ & $\begin{array}{l}4,0 \\
0\end{array}$ & $\begin{array}{l}3,0 \\
0\end{array}$ & 3,00 & $\begin{array}{l}3, \\
33\end{array}$ & $\begin{array}{l}3,6 \\
6\end{array}$ & $\begin{array}{l}3, \\
66\end{array}$ \\
\hline
\end{tabular}


PEDAGOGIKA

Volume 11 (Nomor 1) 2020

Hal. 26-41

\begin{tabular}{|c|c|c|c|c|c|c|c|c|c|c|c|c|c|c|c|c|}
\hline & $\begin{array}{l}\text { media } \\
\text { pembelajaran }\end{array}$ & 5 & 6 & 6 & 6 & 0 & 3 & 6 & & & & & & & & \\
\hline \multirow[t]{3}{*}{4} & Scenario/ & 3 & 3 & 3 , & 3 & 3 , & 3 & 3 , & 3,5 & 3,6 & 3,8 & 3,3 & 3,50 & 3 , & 3,8 & 3 \\
\hline & kegiatan & 1 & 5 & 6 & 8 & 8 & 1 & 3 & 0 & 6 & 3 & 3 & & 66 & 3 & 83 \\
\hline & pembelajaran & 0 & 0 & 6 & 3 & 3 & 6 & 3 & & & & & & & & \\
\hline \multirow[t]{10}{*}{5} & Penilaian hasil & 3 & 3, & 3 , & 3 & 3 , & 3 , & 3 , & 3,5 & 3,7 & 3,7 & 3,2 & 3,25 & 3 , & 3,7 & 3 \\
\hline & belajar & 0 & 4 & 6 & 8 & 9 & 2 & 5 & 0 & 5 & 5 & 5 & & 50 & 5 & 75 \\
\hline & & 5 & 5 & 5 & 0 & 0 & 5 & 0 & & & & & & & & \\
\hline & Jumlah & 1 & 1 & 1 & 1 & 1 & 1 & $\mathbf{1}$ & 18. & 19. & 19. & 16. & 17.2 & 18 & 18. & 19 \\
\hline & & 5. & 7. & 8. & 9. & 9. & 6. & 7. & 00 & 00 & 25 & 50 & 5 & .0 & 75 & .2 \\
\hline & & 2 & 2 & 2 & $\mathbf{0}$ & 5 & 2 & 5 & & & & & & $\mathbf{0}$ & & 5 \\
\hline & & 5 & 5 & 5 & $\mathbf{0}$ & 4 & 5 & $\mathbf{0}$ & & & & & & & & \\
\hline & Rata Rata & 3, & 3. & 3. & 3. & 3. & 3. & 3 , & 3,6 & 3.8 & 3.8 & 3.3 & 3.45 & 3. & 3.7 & 3. \\
\hline & & 0 & 4 & 6 & 8 & 9 & 2 & 5 & 0 & 0 & 5 & 0 & & 60 & 5 & 85 \\
\hline & & 5 & 5 & 5 & 0 & 0 & 5 & 0 & & & & & & & & \\
\hline
\end{tabular}

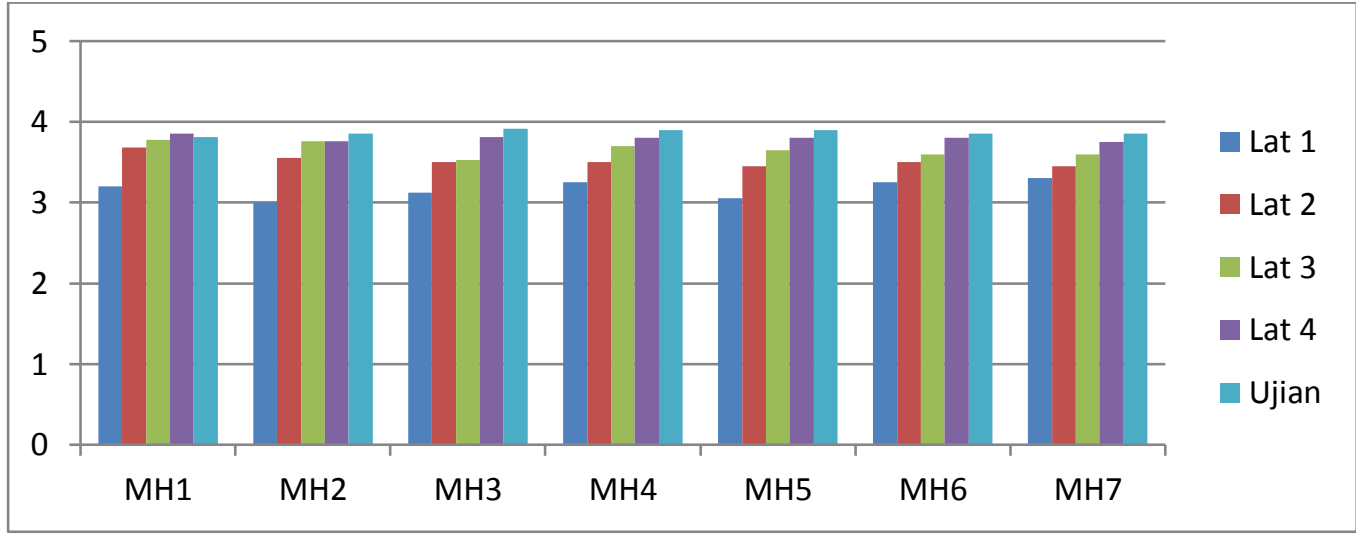

Diagram 1. Penilaian Penyusunan RPP

Dari 5 unsur penilaian penyusunan RPP pada tabel dan diagram diatas dapat dilihat bahwa secara keseluruhan tingkat kompetensi pedagogik dan profesional mahasiswa peserta magang III berdasarkan kemampuan menyusun RPP menunjukkan adanya peningkatan dari latihan 1 , ke latihan 2, latihan 3, latihan 4 dan terakhir pada saat ujian. Dari latihan 1, dengan skor rata rata 3,00 sampai dengan 3,30 dengan kategori baik, meningkat di latihan 2 dengan skor antara 3,45 sampai dengan 3,68 dengan kategori baik dan sangat baik. Di latihan ke 3 meningkat lagi dengan skor rata rata antara 3,53 sampai dengan 3,78 dengan kategori sangat baik, selanjutnya di latihan 4 skornya meningkat menjadi 3,75 sampai dengan 3,85 dengan kategori sangat baik dan terakhir pada waktu ujian skornya meningkat antara 3,81 sampai dengan 3,91 dengan kategori sangat baik.

Peningkatan kompetensi pedagogik dan profesional mahasiswa peserta magang III yang ditunjukkan oleh kemampuannya dalam menyusun RPP dengan unsur unsurnya yaitu merumusan indikator pembelajaran,mengorganisasian dan memilih materi ajar, memilih sumber 


\section{PEDAGOGIKA}

\section{Volume 11 (Nomor 1) 2020}

Hal. 26-41

belajar/media pembelajaran, menyusun scenario/ kegiatan pembelajaran, dan menyusun penilaian hasil belajar tidak terlepas dari bimbingan guru pamong dan dosen pembimbing yang selalu memberikan masukan dan koreksi terhadapan RPP yang disusun mahasiswa peserta magang III sebelum melaksanakan latihan mengajar. Sehingga pemahaman dan kemampuan mahasiswa dalam menyusun RPP menjadi semakin baik dan meningkat terus untuk latihan-latihan mengajar berikutnya

b. Penguasaan Kompetensi Pedagogik dan Profesional dari mahasiswa peserta magang III yang ditunjukkan dari penilaian terhadap pelaksanaan RPP di kelas, dari 4x latihan dan 1x ujian.

Penguasaan kompetensi profesional dan pedagogik berdasarkan penilaian pelaksanaan RPP dapat dilihat pada tabel 03-04 berikut ini;

Tabel 3. Penilaian Pelaksanaan RPP

\begin{tabular}{|c|c|c|c|c|c|c|c|c|c|c|c|c|c|c|c|c|c|c|c|c|}
\hline \multirow[t]{2}{*}{$\begin{array}{l}\mathrm{N} \\
\mathrm{o}\end{array}$} & \multirow[t]{2}{*}{$\begin{array}{l}\text { Unsur yang } \\
\text { dinilai }\end{array}$} & \multicolumn{4}{|c|}{ MH1 } & & \multicolumn{4}{|c|}{ MH2 } & \multicolumn{5}{|c|}{ MH3 } & & & \multicolumn{2}{|c|}{ Latihan dan Ujiar } & Ujiar \\
\hline & & 1 & 2 & 3 & 4 & $\mathbf{U}$ & 1 & 2 & 3 & 4 & $\mathbf{U}$ & 1 & 2 & 3 & 4 & $\mathbf{U}$ & 1 & 2 & 3 & 4 \\
\hline \multirow[t]{4}{*}{1} & Pra & 3. & 3.5 & 4. & 4. & 4.0 & 3. & 3. & 3 & 4. & 4. & 3. & 3. & 4. & 4. & 4. & 3. & 4. & 4. & 4. \\
\hline & pembelajaran & 00 & 0 & 00 & 00 & 0 & 00 & 5 & . & 0 & 0 & 0 & 5 & 0 & 0 & 0 & 5 & 0 & 0 & 0 \\
\hline & & & & & & & & 0 & 5 & 0 & 0 & 0 & 0 & 0 & 0 & 0 & 0 & 0 & 0 & 0 \\
\hline & & & & & & & & & 0 & & & & & & & & & & & \\
\hline \multirow[t]{4}{*}{2} & Membuka & 3. & 3.0 & 3,5 & 4. & 4,0 & 3. & 3. & 3 & 4. & 4. & 3. & 3. & 3. & 3. & 3. & 3. & 3. & 4. & 4. \\
\hline & pembelajaran & 00 & 0 & 0 & 00 & 0 & 00 & 0 & . & 0 & 0 & 0 & 0 & 0 & 5 & 5 & 0 & 5 & 0 & 0 \\
\hline & & & & & & & & 0 & 5 & 0 & 0 & 0 & 0 & 0 & 0 & 0 & 0 & 0 & 0 & 0 \\
\hline & & & & & & & & & 0 & & & & & & & & & & & \\
\hline
\end{tabular}

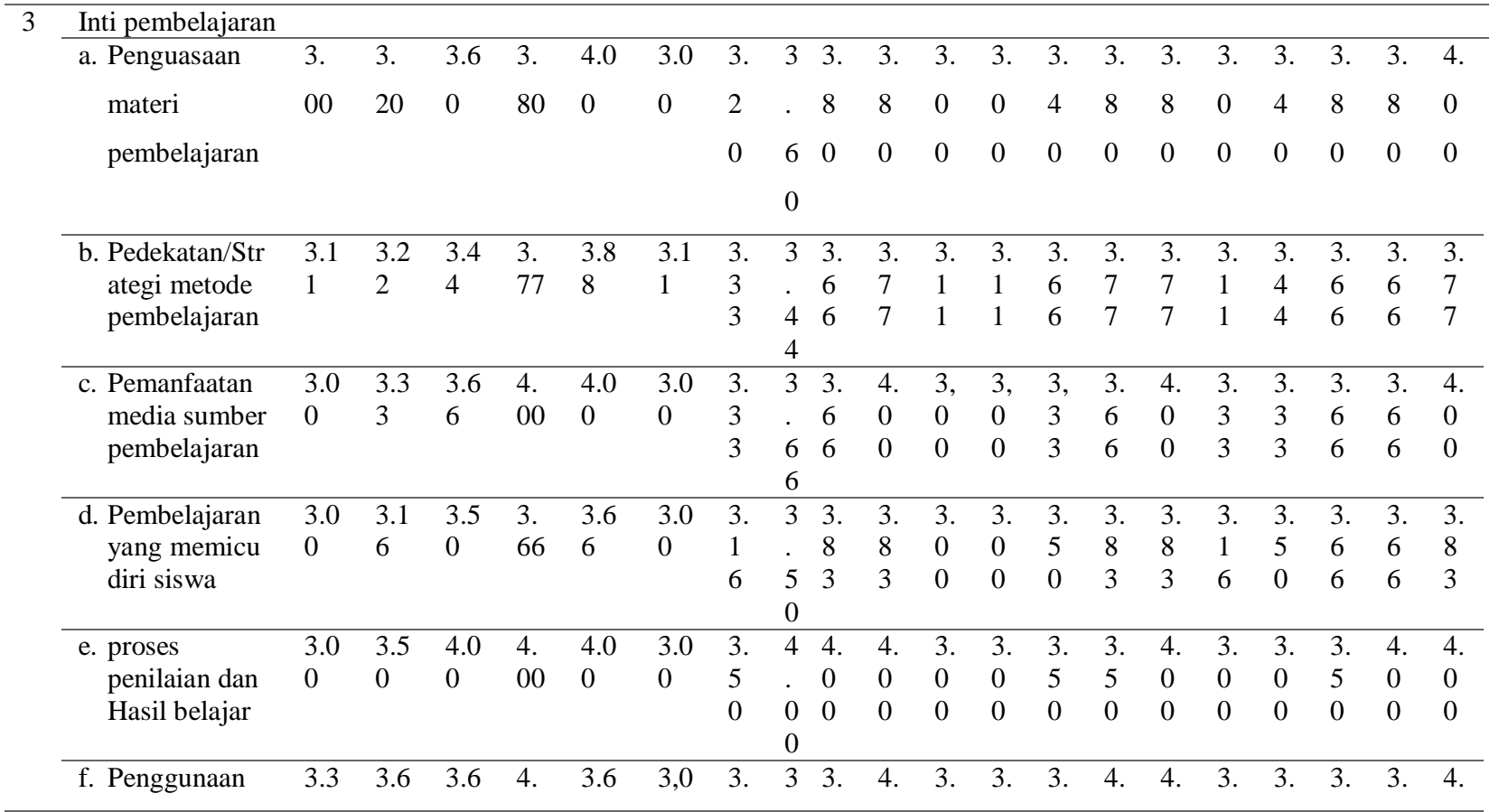


PEDAGOGIKA

Volume 11 (Nomor 1) 2020

Hal. 26-41

\begin{tabular}{|c|c|c|c|c|c|c|c|c|c|c|c|c|c|c|c|c|c|c|c|c|c|}
\hline \multirow{2}{*}{\multicolumn{2}{|c|}{ Bahasa }} & 3 & 6 & 6 & 00 & 6 & 0 & 0 & . & 6 & 0 & 0 & 0 & 3 & 0 & 0 & 3 & 6 & 6 & 6 & 0 \\
\hline & & & & & & & & 0 & 3 & 6 & 0 & 0 & 0 & 3 & 0 & 0 & 3 & 6 & 6 & 6 & 0 \\
\hline & & & & & & & & & 3 & & & & & & & & & & & & \\
\hline \multirow[t]{13}{*}{4} & PENUTUP & 3.0 & 3.0 & 3.5 & 3. & 4.0 & 3.0 & 3 & 3 & 3 & 3. & 3. & 3. & 3. & 4. & 4. & 3. & 3. & 3. & 3. & 4. \\
\hline & & 0 & 0 & 0 & 50 & 0 & 0 & 0 & , & 5 & 5 & 0 & 0 & 5 & 0 & 0 & 0 & 5 & 5 & 5 & 0 \\
\hline & & & & & & & & 0 & 5 & 0 & 0 & 0 & 0 & 0 & 0 & 0 & 0 & 0 & 0 & 0 & 0 \\
\hline & & & & & & & & & 0 & & & & & & & & & & & & \\
\hline & Jumlah & 27. & 29. & 32. & 34 & 35. & 27. & 2 & 3 & 3 & 3 & 2 & 2 & 3 & 3 & 3 & 2 & 3 & 3 & 3 & 3 \\
\hline & & 45 & 57 & 86 & .7 & 2 & 11 & 9. & 2 & 4. & 4. & 7. & 7. & 1. & 4. & 4. & 8. & 1. & 3. & 3. & 5. \\
\hline & & & & & 3 & & & 0 & . & 1 & 9 & 1 & 6 & 2 & 0 & 9 & 4 & 3 & 4 & 9 & 6 \\
\hline & & & & & & & & 2 & $\mathbf{0}$ & 1 & & 1 & 1 & 2 & 6 & & 3 & 3 & 4 & 4 & \\
\hline & & & & & & & & & 3 & & & & & & & & & & & & \\
\hline & Rata-Rata & 3.0 & 3.2 & 3.6 & 3. & 3.9 & 3.0 & 3. & 3 & 3. & 3. & 3. & 3. & 3. & 3. & 3. & 3. & 3. & 3. & 3. & 3. \\
\hline & & 5 & 8 & 5 & 85 & 1 & 1 & 2 & . & 7 & 8 & 0 & 0 & 4 & 7 & 8 & 1 & 4 & 7 & 7 & 9 \\
\hline & & & & & & & & 2 & 5 & 9 & 7 & 1 & 6 & 6 & 8 & 7 & 5 & 8 & 1 & 7 & 5 \\
\hline & & & & & & & & & 5 & & & & & & & & & & & & \\
\hline
\end{tabular}

Tabel 4. Penilaian Pelaksanaan RPP

\begin{tabular}{|c|c|c|c|c|c|c|c|c|c|c|c|c|c|c|c|c|}
\hline \multirow[t]{3}{*}{ No } & & \multicolumn{5}{|c|}{ MH5 } & \multicolumn{5}{|c|}{ MH6 } & \multicolumn{5}{|c|}{ MH7 } \\
\hline & \multirow[t]{2}{*}{ Unsur yang dinilai } & \multicolumn{5}{|c|}{ Latihan dan Ujian } & \multicolumn{5}{|c|}{ Latihan dan Ujian } & \multicolumn{5}{|c|}{ Latihan dan Ujian } \\
\hline & & 1 & 2 & 3 & 4 & $\mathbf{U}$ & 1 & 2 & 3 & 4 & $\mathbf{U}$ & 1 & 2 & 3 & 4 & $\mathbf{U}$ \\
\hline \multirow[t]{2}{*}{1} & Pra pembelajaran & 3. & 3. & 3. & 3. & 4. & 3. & 3. & 3. & 4. & 4.00 & 3.00 & 3.00 & 3.50 & 3.50 & 4.00 \\
\hline & & 50 & 50 & 50 & 50 & 00 & 00 & 00 & 50 & 00 & & & & & & \\
\hline \multirow[t]{2}{*}{2} & Membuka pembelajaran & 3. & 3. & 3. & 3. & 4. & 3. & 3. & 3. & 4. & 3.50 & 3.00 & 3.00 & 3.50 & 3.50 & 3.50 \\
\hline & & 00 & 50 & 50 & 50 & 00 & 00 & 50 & 50 & 00 & & & & & & \\
\hline \multirow[t]{9}{*}{3} & Inti pembelajaran & & & & & & & & & & & & & & & \\
\hline & a. Penguasaan materi & 3. & 3. & 3. & 3. & 3. & 3. & 3. & 3. & 3. & 3.80 & 3.00 & 3.40 & 3.80 & 3.80 & 3.80 \\
\hline & pembelajaran & 20 & 40 & 40 & 60 & 80 & 00 & 20 & 60 & 80 & & & & & & \\
\hline & $\begin{array}{l}\text { b. Pedekatan/Strategi metode } \\
\text { pembelajaran }\end{array}$ & $\begin{array}{l}3 . \\
00\end{array}$ & $\begin{array}{l}3 . \\
66 \\
\end{array}$ & $\begin{array}{l}3 . \\
66\end{array}$ & $\begin{array}{l}3 . \\
77\end{array}$ & $\begin{array}{l}3 . \\
77\end{array}$ & $\begin{array}{l}3 . \\
11\end{array}$ & $\begin{array}{l}3 . \\
22\end{array}$ & $\begin{array}{l}3 . \\
44\end{array}$ & $\begin{array}{l}3 . \\
66\end{array}$ & 3.77 & 3.00 & 3.22 & 3.55 & 3.77 & 3.77 \\
\hline & $\begin{array}{ll}\text { c. } & \text { Pemanfaatan media } \\
\text { sumber pembelajaran }\end{array}$ & $\begin{array}{l}3 . \\
00\end{array}$ & $\begin{array}{l}3 . \\
33\end{array}$ & $\begin{array}{l}3 . \\
66\end{array}$ & $\begin{array}{l}3 . \\
66\end{array}$ & $\begin{array}{l}4 . \\
00\end{array}$ & $\begin{array}{l}3 . \\
33\end{array}$ & $\begin{array}{l}3 . \\
33\end{array}$ & $\begin{array}{l}3 . \\
66\end{array}$ & $\begin{array}{l}4 . \\
00\end{array}$ & 4.00 & 3.33 & $\begin{array}{l}3 . \\
33\end{array}$ & 3.66 & 4.00 & 4.00 \\
\hline & $\begin{array}{l}\text { d. Pembelajaran yang } \\
\text { memicu diri siswa }\end{array}$ & $\begin{array}{l}3 . \\
00\end{array}$ & $\begin{array}{l}3 . \\
50\end{array}$ & $\begin{array}{l}3 . \\
66\end{array}$ & $\begin{array}{l}3 . \\
66\end{array}$ & $\begin{array}{l}3 . \\
83\end{array}$ & $\begin{array}{l}3 . \\
00\end{array}$ & $\begin{array}{l}3 . \\
16\end{array}$ & $\begin{array}{l}3 . \\
50\end{array}$ & $\begin{array}{l}3 . \\
66\end{array}$ & 3.66 & 3.16 & 3.16 & 3.50 & 3.83 & 3.83 \\
\hline & $\begin{array}{l}\text { e. proses penilaian dan Hasil } \\
\text { belajar }\end{array}$ & $\begin{array}{l}3 . \\
00\end{array}$ & $\begin{array}{l}3 . \\
00\end{array}$ & $\begin{array}{l}3 . \\
50\end{array}$ & $\begin{array}{l}3 . \\
50\end{array}$ & $\begin{array}{l}4 . \\
00\end{array}$ & $\begin{array}{l}3 . \\
00\end{array}$ & $\begin{array}{l}3 . \\
50\end{array}$ & $\begin{array}{l}3 . \\
50\end{array}$ & $\begin{array}{l}3 . \\
50\end{array}$ & 4.00 & 3.00 & 3.50 & 3.50 & 4.00 & 4.00 \\
\hline & f. Penggunaan Bahasa & 3. & 3. & 3. & 3. & 4. & 3. & 3. & 3. & 4. & 4.00 & 3.00 & 3.00 & 3.33 & 3.66 & 4.00 \\
\hline & & 00 & 66 & 66 & 66 & 00 & 00 & 33 & 66 & 00 & & & & & & \\
\hline \multirow[t]{3}{*}{4} & PENUTUP & 3. & 3. & 3. & 3. & 4. & 3. & 3. & 3. & 3. & 4.00 & 3.00 & 3.00 & 3.50 & 4.00 & 4.00 \\
\hline & & 00 & 00 & 50 & 50 & 00 & 00 & 00 & 50 & 50 & & & & & & \\
\hline & Jumlah & 27 & 30 & 32 & 32 & 35 & 27 & 29 & 31 & 34 & 34.7 & 27.49 & 28.61 & 31.84 & 34.06 & 34.9 \\
\hline
\end{tabular}

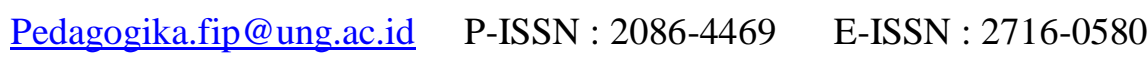




\begin{tabular}{rrrrrrrrrrrrrrrrr}
\hline & .7 & .5 & .0 & .3 & .4 & .4 & .2 & .8 & .1 & 3 & \\
& & 5 & 4 & 5 & & 4 & 4 & 6 & 2 & & \\
\hline Rata-Rata & 3. & 3. & 3. & 3. & 3. & 3. & 3. & 3. & 3. & 3.85 & 3.05 & 3.17 & 3.53 & 3.78 & 3.87 & \\
& 07 & 39 & 56 & 59 & 93 & 04 & 24 & 54 & 79 & & & \\
\hline
\end{tabular}

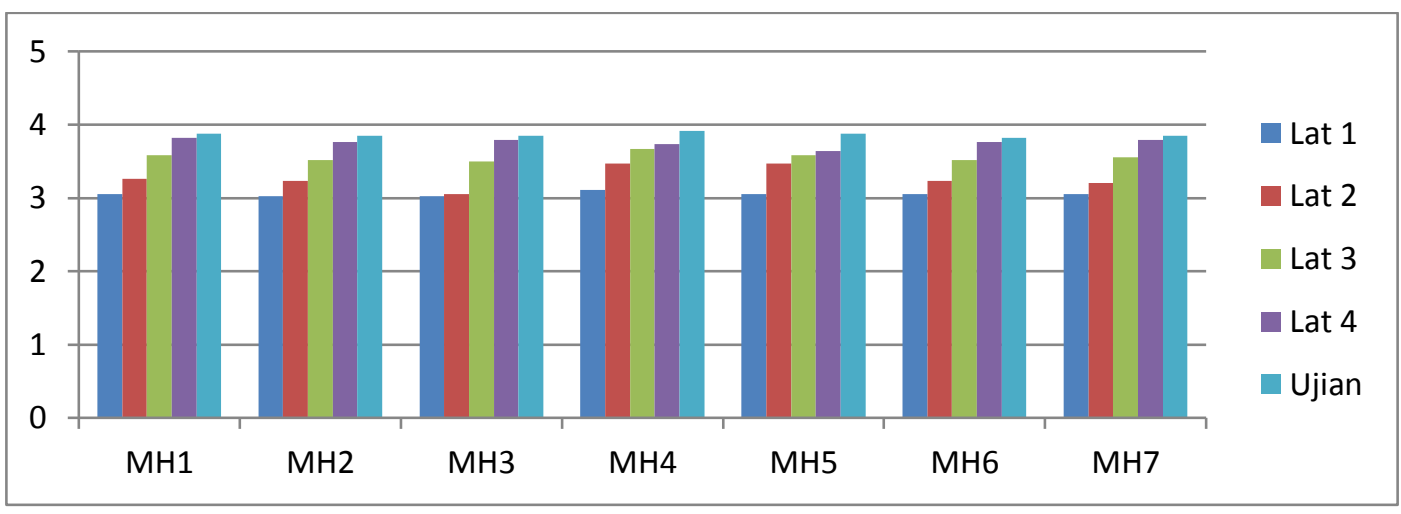

Diagram 2. Penilaian Pelaksanaan RPP

Dari 4 unsur penilaian pelaksanaan RPP pada tabel dan diagram diagram di atas dapat dilihat bahwa secara keseluruhan tingkat penguasaan kompetensi pedagogik dan profesional mahasiswa peserta magang III berdasarkan kemampuan mengajar atau melaksanakan RPP di kelas menunjukkan adanya peningkatan dari latihan 1 , ke latihan 2, latihan 3, latihan 4 dan terakhir pada saat ujian. Pada latihan 1, peserta magang III mendapakan skor rata rata antara 3,02 sampai dengan 3,11 dengan kategori baik, meningkat di latihan 2 dengan skor rata rata 3,05 sampai dengan 3,47 dengan kategori baik. Selanjutnya pada latihan 3 meningkat lagi dengan skor rata rata antara 3,50 sampai dengan 3,67 dengan kategori sangat baik, dan pada latihan 4 mendapatkan skor rata rata antara
3,64 sampai dengan 3,82 dengan kategori sangat baik. Terakhir pada saat ujian mendapatkan skor rata-rata antara 3,82 sampai dengan 3,95 dengan kategori sangat baik.

Berdasarkan rata-rata skor yang diperoleh mahasiswa peserta magang III dari penilaian pelaksanaan RPP menunjukkan bahwa kemampuan/kompetensi pedagogik dan profesional mahasiswa dalam melaksanakan pembelajaran di kelas dengan 4 unsur yang dinilai yaitu pra pembelajaran, membuka pembelajaran, inti pembelajaran yang terdiri dari penguasaan materi pembelajaran, pedekatan/ strategi/ metode pembelajaran, pemanfatan media/sumber pembelajaran, pembelajaran yang memicu diri siswa, proses penilaian 
PEDAGOGIKA

Volume 11 (Nomor 1) 2020

Hal. 26-41

dan hasil belajar., penggunaan bahasa, dan penutup sudah baik, dan pada setiap latihan mengajar berikutnya selalu ada peningkatan skor penilaiannya.

Hal ini terjadi karena mahasiswa aktif untuk konsultasi atau bertanya ke guru pamong dan dosen pembimbing sebelum maksanakan pembelajaran, sehingga kesalahan atau kekurangan pada saat mengajar di kelas bisa dicegah sedini mungkin. Walaupun mungkin masih ada kekurangan kekurangan tetapi tidak dalam hal yang bersifat prinsip, misalnya kesalahan konsep materi pembelajaran (penguasaan materi pembelajaran). Kekurangan kekurangan yang masih ada misalnya kurang melibatkan siswa dalam penggunaan media pembelajaran dan kurang mengaktifkan siswa secara merata.

Berdasarkan hasil penilaian terhadap penguasaan kompetensi pedagogik dan profesional, yang ditunjukkan dari penyusunan RPP dan pelaksanaan RPP di kelas mulai latihan 1,2,3,4,dan ujian dari 7 orang mahasiswa peserta magang III menunjukkan bahwa mahasiswa peserta magang III progdi PPKn FKIP UKSW sudah siap dalam melaksanakan tugas dan tanggung jawabnya sebagai calon guru yang profesional.

$$
\text { Hasil penilaian terhadap }
$$

penguasaan kompetensi pedagogik dan profesional tersebut juga didukung/diperkuat dengan hasil wawancara terhadap guru pamong di SMK Negeri 2 dan SMK Negeri 3 Salatiga, serta dosen pembimbing yang diuraikan sebagai berikut;

1. Ibu Endang selaku guru pamong di SMK Negeri 2 Salatiga menuturkan bahwa penguasaan kompetensi pedagogik dan profesional mahasiswa peserta magang yang ditunjukkan dari penyusunan RPP dan pelaksanaan RPP di kelas, dari latihan 1 ke latihan 2,3,4 dan ujian makin meningkat menjadi lebih baik. Memang pada saat latihan 1 khususnya tentang penguasaan materi dan penguasaan kelas mahasiswa agak gerogi dalam menyampaikan materi dan mengelola kelas agar tidak ramai tetapi di latihan selanjutnya sudah tidak grogi lagi.

2. Ibu Rina selaku guru pamong di SMK Negeri 2 Salatiga menuturkan bahwa mahasiswa dalam penyusunan RPP dan pelaksanaan RPP di dalam kelas, tidak ada kendala hanya masih terbawa suasana kelas misalnya menyebut peserta didik dengan sebutan teman akan tetapi saya mengingatkannya jadi tidak ada masalah lagi dalam proses belajar mengajar. 
PEDAGOGIKA

Volume 11 (Nomor 1) 2020

Hal. 26-41

3. Bapak Yuli selaku guru pamong di SMK Negeri 3 Salatiga menuturkan bahwa mahasiswa pada latihan 1 masih ragu ragu dalam menyampaikan materi akan tetapi untuk latihan berikutnya mahasiswa yang saya bimbing sudah bisa menunjukkan di depan peserta didik bahwa dia adalah guru.

4. Ibu Rida selaku guru pamong di SMK Negeri 3 menuturkan bahwa saya lihat mahasiswa yang saya bimbing sudah mengetahui apa saja yang harus dipersiapkan dalam mengajar, dari penguasaan materi hingga berinteraksi dengan siswa di dalam kelas juga mahasiswa sudah siap untuk menjadi calon guru dan menjadi contoh bagi peserta didik. Jadi tidak ada masalah untuk mahasiswa yang saya bimbing.

5. Ibu Rita selaku guru pamong di SMK Negeri 3 Salatiga menuturkan bahwa kompetensi profesional dan pedagogik bagi mahasiswa sudah diajarkan ada saat microteaching, jadi mahasiswa sudah tahu bagaimana kondisi kelas dan pada saat mahasiswa ini mengajar tidak ada masalah yang serius dalam kelas.

6. Ibu Nani selaku dosen pembimbing di SMKN 2 dan SMKN 3 Salatiga menyatakan bahwa mahasiswa peserta magang III telah menguasai kompetensi pedagogik, profesional dengan baik. Pada saat ujian baik dalam penyusunan RPP maupun pelaksanaan RPP di kelas tidak ada permasalahan yang dihadapi mahasiswa peserta magang III, proses pembelajaran terlaksana dengan baik dan melibatkan siswa secara aktif di kelas.

Berdasarkan hasil observasi terhadap mahasiswa peserta magang III pada saat ujian juga menunjukkan penguasaan kompetensi pedagogik dan profesional yang baik dari mahasiswa, tidak ada masalah dalam penyampaian materi dan siswa juga terlibat aktif di kelas.

c. Kompetensi Kepribadian Dari

Mahasiswa Peserta Magang III;

Berdasarkan penilaian terhadap kompetensi kepribadian mahasiswa dapat dilihat dalam tabel 05 dan diagram berikut ini.

Tabel 5. Penilaian Kompetensi kepribadian

\begin{tabular}{llccccccc}
\hline No & \multicolumn{1}{c}{ Unsur yang dinilai } & MH & MH & MH & MH & MH & MH & MH \\
\hline 1 & $\mathbf{1}$ & $\mathbf{2}$ & $\mathbf{3}$ & $\mathbf{4}$ & $\mathbf{5}$ & $\mathbf{6}$ & $\mathbf{7}$ \\
\hline $\begin{array}{l}\text { Menghargai peserta didik tanpa } \\
\text { membedakan keyakinan yang } \\
\text { dianut, suku, adat istiadat. }\end{array}$ & 4 & 4 & 4 & 4 & 4 & 4 & 4 \\
daerah asal dan gender & & & & & & & & \\
\hline
\end{tabular}

Pedagogika.fip@ung.ac.id P-ISSN : 2086-4469 E-ISSN : 2716-0580 
PEDAGOGIKA

Volume 11 (Nomor 1) 2020

Hal. 26-41

\begin{tabular}{ccccccccc}
\hline 2 & $\begin{array}{l}\text { Berperilaku jujur, tegas dan } \\
\text { manusiawi. }\end{array}$ & 4 & 4 & 4 & 4 & 4 & 4 & 4 \\
\hline 3 & $\begin{array}{l}\text { Berperilaku yang } \\
\text { mencerminkan ketakwaan dan } \\
\text { akhlak mulia }\end{array}$ & 4 & 4 & 4 & 4 & 4 & 4 & 4 \\
\hline 4 & $\begin{array}{l}\text { Menampilkan diri sebagai } \\
\text { pribadi yang mantap, stabil, } \\
\text { dewasa, bijaksana, dan } \\
\text { berwibawa }\end{array}$ & 4 & 4 & 4 & 3 & 4 & 3 & 3 \\
\hline 5 & $\begin{array}{l}\text { Bersikap dan berperilaku sesuai } \\
\text { kode etik profesi guru }\end{array}$ & 4 & 4 & 4 & 4 & 4 & 4 & 4 \\
\hline 6 & $\begin{array}{l}\text { Memiliki kebanggaan menjadi } \\
\text { guru dan percaya pada diri } \\
\text { sendiri }\end{array}$ & 4 & 4 & 4 & 4 & 4 & 4 & 4 \\
\hline 7 & $\begin{array}{l}\text { Menunjukan etos kerja dan } \\
\text { tanggung jawab yang tinggi } \\
\text { terhadap tugas tugasnya. }\end{array}$ & 4 & 4 & 4 & 3 & 4 & 3 & 3 \\
\hline$\quad$ JUMLAH & $\mathbf{2 8}$ & $\mathbf{2 8}$ & $\mathbf{2 8}$ & $\mathbf{2 6}$ & $\mathbf{2 8}$ & $\mathbf{2 6}$ & $\mathbf{2 6}$ \\
\hline Rata-rata & $\mathbf{4 . 0 0}$ & $\mathbf{4 . 0 0}$ & $\mathbf{4 . 0 0}$ & $\mathbf{3 . 7 1}$ & $\mathbf{4 . 0 0}$ & $\mathbf{3 . 7 1}$ & $\mathbf{3 . 7 1}$ \\
\hline & $\quad$ & & & & & & \\
\hline
\end{tabular}

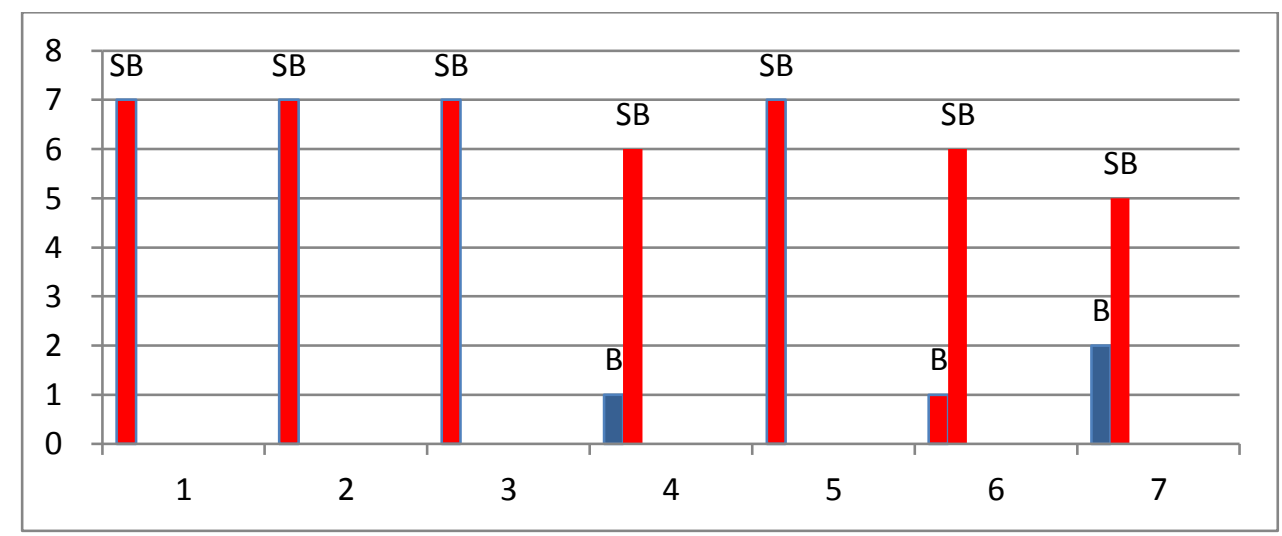

\section{Diagram 3. Penilaian Kompetensi Kepribadian}

Berdasarkan tabel dan diagram diatas menunjukkan bahwa kompensi kepribadian mahasiswa progdi PPKn peserta magang III dinilai sangat baik dan baik. Dari ketujuh indikator yang dinilai sebagian besar 4 orang mahasiswa dinilai sangat baik dengan skor rata-rata 4 , yang dinilai baik dengan skor 3 hanya pada indikator 4 dan 7 ada 3 orang. mahasiswa, namun skor rata-ratanya 3,71 dengan kategori sangat baik. Hal ini menunjukkan bahwa kompetensi kepribadian mahasiswa magang III dengan indikator yang dinilai yaitu menghargai peserta didik tanpa membedakan keyakinan yang dianut, suku, adat istiadat, daerah asal dan gender; Berperilaku jujur, tegas dan manusiawi; Berperilaku yang mencerminkan ketakwaan dan akhlak mulia; Menampilkan diri sebagai pribadi yang mantap, stabil, dewasa, bijaksana, dan berwibawa; Bersikap dan berperilaku sesuai kode etik 


\section{PEDAGOGIKA}

\section{Volume 11 (Nomor 1) 2020}

Hal. 26-41

profesi guru; Memiliki kebanggaan menjadi guru dan percaya pada diri sendiri; dan Menunjukkan etos kerja dan tanggung jawab yang tinggi terhadap tugas tugasnya rata-rata sangat baik. d. Kompetensi Sosial Mahasiswa Peserta Magang III;

Kompetensi sosial mahasiswa magang III dinilai dari 5 indikator yang hasilnya dapat dilihat pada tabel dan diagram berikut ini;

Tabel 6. Penilaian Kompetensi Sosial

\begin{tabular}{llccccccc}
\hline No & \multicolumn{1}{c}{ Unsur yang dinilai } & MH1 & MH2 & MH3 & MH4 & MH5 & MH6 & MH7 \\
\hline 1 & 4 & 4 & 4 & 4 & 4 & 4 & 4 \\
& $\begin{array}{l}\text { Bersikap terbuka dan objekif } \\
\text { terhadap kepala sekolah, guru, } \\
\text { peserta didik dan orang tua peserta } \\
\text { didik selama magang III }\end{array}$ & & & & & & & \\
\hline 2 & $\begin{array}{l}\text { Tidak besikap diskripminatif } \\
\text { terhadap warga sekolah karena } \\
\text { perbedaan agama, suku, jenis } \\
\text { kelamin, latar belakang keluarga, } \\
\text { dan status sosial ekonomi. }\end{array}$ & 4 & 4 & 4 & 4 & 4 & 4 & 4 \\
\hline 3 & $\begin{array}{l}\text { Berani mengambil inisiatif untuk } \\
\text { berkomunikasi dalam menjalankan } \\
\text { tugas tugas di sekolah }\end{array}$ & 4 & 4 & 4 & 3 & 4 & 3 & 4 \\
\hline 4 & $\begin{array}{l}\text { Menjalin dan memelihara } \\
\text { kebersamaan dan kelompok } \\
\text { diantara sesama peserta magang III }\end{array}$ & 4 & 4 & 4 & 4 & 4 & 4 & 4 \\
\hline 5 & $\begin{array}{l}\text { Menunjukan sikap ramah dan } \\
\text { bersabahat dalam rangka } \\
\text { menciptakan iklim sekolah yang } \\
\text { kondusif untuk belajar }\end{array}$ & 4 & 4 & 4 & 4 & 4 & 4 & 4 \\
\hline$\quad$ jumlah & & & & & & & & \\
\hline Rata-rata & $\mathbf{2 0}$ & $\mathbf{2 0}$ & $\mathbf{2 0}$ & $\mathbf{1 9}$ & $\mathbf{2 0}$ & $\mathbf{1 9}$ & $\mathbf{1 9}$ \\
\hline & $\quad \mathbf{4 . 0 0}$ & $\mathbf{4 . 0 0}$ & $\mathbf{3 . 8 0}$ & $\mathbf{4 . 0 0}$ & $\mathbf{3 . 8 0}$ & $\mathbf{3 . 8 0}$ \\
\hline
\end{tabular}

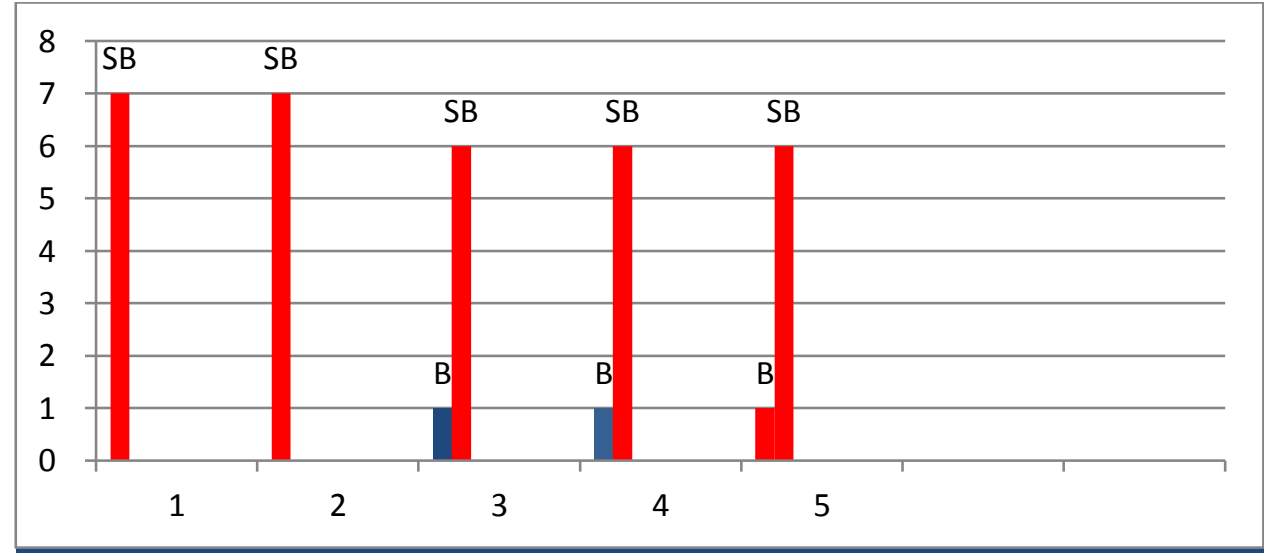

Diagram 4. Penilaian Kompetensi Sosial

Berdasarkan tabel dan diagram Sosial mahasiswa progdi PPKn peserta diatas menunjukan bahwa kompentensi magang III dinilai sangat baik. Dari kelima Pedagogika.fip@ung.ac.id P-ISSN : 2086-4469 E-ISSN : 2716-0580 
PEDAGOGIKA

Volume 11 (Nomor 1) 2020

Hal. 26-41

indikator yang dinilai sebagian besar 4 orang mahasiswa dinilai sangat baik dengan skor rata-rata 4, yang dinilai baik dengan skor 3 hanya pada indikator 3 dan 4 ada 3 orang mahasiswa, namun skor rataratanya 3,80 dengan kategori sangat baik. Hal ini menunjukkan bahwa kompentensi sosial mahasiswa magang III dengan kelima indikator yang dinilai yaitu Bersikap terbuka dan objekif terhadap kepala sekolah, guru, peserta didik dan orang tua peserta didik selama magang III; Tidak besikap diskriminatif terhadap warga sekolah karena perbedaan agama, suku, jenis kelamin, latar belakang keluarga, dan status sosial ekonomi; Berani mengambil inisiatif untuk berkomunikasi dalam menjalankan tugas tugas di sekolah; Menjalin dan memelihara kebersamaan dan kelompok diantara sesama peserta magang III; dan Menunjukan sikap ramah dan bersabahat dalam rangka menciptakan iklim sekolah yang kondusif untuk belajar rata-rata sangat baik.

\section{HASIL PENELITIAN DAN PEMBAHASAN}

Berdasarkan hasil penelitian menunjukkan bahwa tingkat penguasaan kompetensi pedagogik dan professional mahasiswa yang ditunjukkan dari kemampuan menyusun RPP dan melaksanakan RPP di kelas mulai latihan 1,2,3,4 dan ujian rata rata dari kategori baik meningkat menjadi sangat baik. Demikian juga kompetensi kepribadian dan kompetensi sosial juga dinilai rata rata sangat baik.

Hal ini menunjukkan bahwa tingkat penguasaan keempat kompetensi guru yang profesional dari mahasiswa peserta magang III di SMKN 2 dan SMKN 3 Salatiga sudah baik, dan menunjukan kesiapan mahasiswa dalam melaksanakan program magang III di sekolah, sekaligus menunjukkan kesiapan mahasiswa untuk menjadi calon guru yang profesional. Hal ini tidak lepas dari bekal yang diberikan oleh Progdi PPKn melalui kurikulumnya. Untuk dapat mengikuti program magang III mahasiswa harus lulus Matakuliah Dasar Kependidikan (MKDK), Matakuliah Proses Belajar Mengajar (MKPBM), Sebagian besar mata kuliah Bidang Studi (MKBS), program Magang I, Magang II dan Micro Teaching dengan jumlah minimal 110 sks.

Dengan bekal mata kuliah yang disajikan dalam kurikulum dan diberikan dalam perkuliahan di kelas serta program magang I dan II yang memberikan pengenalan terhadap kondisi lingkungan dan budaya sekolah, serta penyusunan perangkat pembelajaran secara praktik di sekolah, bahkan juga dilengkapi dengan praktek micro teaching, benar benar dapat membekali mahasiswa dengan penguasaan kompetensi pedagogik, profesional, $\underline{\text { Pedagogika.fip@ung.ac.id } \quad P-I S S N ~: ~ 2086-4469 ~ E-I S S N ~: ~ 2716-0580 ~}$ 
PEDAGOGIKA

Volume 11 (Nomor 1) 2020

Hal. 26-41

kepribadian, dan sosial yang memadai dan baik untuk dapat melaksanakan tugas dan tanggung jawabnya dalam pelaksanaan program magang III.

Sesuai pendapat Oemar Hamalik,(2009:171-172 ) Magang III atau PPL adalah serangkaian kegiatan diprogramkan bagi mahasiswa LPTK, yang meliputi baik latihan mengajar maupun di luar mengajar. Kegiatan ini merupakan ajang untuk membentuk dan membina kompetensi-kompetensi profesional yang disyaratkan oleh pekerjaan guru atau lembaga pendidikan lainnya. Sasaran yang ingin dicapai adalah kompetensi calon pendidik yang memiliki seperangkat pengetahuan, kerampilan, nilai dan sikap, serta pola tingkah laku yang diperlukan bagi profesinya serta cakap dan tepat menggunakan di dalam menyelenggarakan pendidikan dan pengajaran, baik di sekolah maupun diluar sekolah.

Oleh karena itu, mahasiswa calon guru harus mendapatkan bekal yang memadai agar dapat menguasai sejumlah kompetensi yang diharapkan tersebut baik melalui preservice training maupun inservice training. Salah satu bentuk preservice training calon guru tersebut adalah melalui pembentukan kemampuan dasar mengajar (teaching skill) baik secara teoritis maupun praktis.
Secara praktis, bekal kemampuan mengajar dapat dilatih sejak dini melalui mata kuliah proses belajar mengajar (perencanaan pembelajaran, metode pembelajaran, evaluasi pembelajaran) didalam kelas dan micro teaching. (Tim Penyusun Buku Panduan Pengajaran Mikro UNY,2011:1).

Selain itu melalui program magang I dan II yang telah dilaksanakan sebagai ajang pelatihan untuk menerapkan berbagai kompetensi meliputi pengetahuan, sikap, dan ketrampilan. untuk membangun landasan jati diri pendidik dan memantapkan kompetensi akademik kependidikan, serta memberi pengalaman kepada mahasiswa/calon guru dalam menelaah, merancang, dan mengembangkan segenap komponen dalam sistem pembelajaran di sekolah.(Buku Panduan Magang I, 2017:7 dan magang II 2017:10), benar benar dapat membekali mahasiswa magang III untuk siap dan bertanggung jawab melaksanakan program magang III dan menjadi calon guru yang profesional.

\section{KESIMPULAN}

Tingkat penguasaan kompetensi profesional, pedagogik, kepribadian dan sosial dari mahasiswa peserta magang iii secara keseluruhan rata rata dalam kategori baik dan sangat baik yang menunjukkan kesiapan mahasiswa Progdi PPKn dalam melaksanakan tugas dan tanggung jawabnya dalam pelaksanaan program 
PEDAGOGIKA

Volume 11 (Nomor 1) 2020

Hal. 26-41

magang III dan sebagai calon guru yang

Profesional.

\section{REFERENCES}

Heriansyah, H. (2010). Metode Penelitian Kualitatif. Jakarta: Salemba.

Hamalik, Oemar. 2009. Kurikulum dan Pembelajaran. Jakarta. Bumi Aksara

Moleong, Lexy J. (2010), Metodologi penelitian kualitatif. Remaja Rosdakarya, Bandung

Padmomartono, Sumardjono. 2009. Pengembangan Kompetensi Kepribadian Guru. Salatiga: Widya Sari Press
P3SP- FKIP, 2017. Buku panduan magang I, Universitas Kristen Satya Wacana tahun 2017.

P3SP- FKIP, 2017. Buku panduan magang II, Universitas Kristen Satya Wacana tahun 2017.

P3SP- FKIP, 2017. Buku panduan magang III, Universitas Kristen Satya Wacana tahun 2017

UNY,2011 Tim Penyusun Buku Panduan Pengajaran Mikro.

Undang-Undang Nomor 14 Tahun 2005 tentang Guru dan Dosen 